\title{
A study on the effect of productivity on the wage level, with emphasis on the productivity of skilled and unskilled labor
}

\author{
Hossein Akbari Fard $^{a}$, Sayyed Abdolmajid Jalaee ${ }^{\mathrm{b}}$ and Seyed Bagher Fazayel Ardakani ${ }^{\mathrm{c}^{*}}$
}

\begin{abstract}
${ }^{a}$ Assistant Professor, Department of Economics, Shahid Bahonar University of Kerman, Kerman, Iran
${ }^{b}$ Professor, Department of Economics, Shahid Bahonar University of Kerman, Kerman, Iran ${ }^{c} P h D$ Student in Economics, Department of Economics, Shahid Bahonar University of Kerman, Kerman, Iran

\begin{tabular}{|c|c|}
\hline$\overline{C H R O N I C L E}$ & A B S T RACT \\
\hline $\begin{array}{l}\text { Article history: } \\
\text { Received November } 1,2017 \\
\text { Received in revised format } \\
\text { November } 112017 \\
\text { Accepted January } 72018 \\
\text { Available online } \\
\text { January } 82018 \\
\text { Keywords: } \\
\text { Wages } \\
\text { Labor productivity } \\
\text { Skilled labor productivity } \\
\text { Unskilled labor productivity } \\
\text { Self-explanatory patterns with }\end{array}$ & $\begin{array}{l}\text { The productivity of labor and wages are two important variables in the market. Identification } \\
\text { of the relationship between the labor and the wages can help policymakers and employers make } \\
\text { important decisions about workers' wages. This research uses the statistical data from } 1974 \text { to } \\
2014 \text { in Iran to explore the effect of the total labor productivity as well as the productivity of } \\
\text { skilled and unskilled labor on the wage level. The results of the research in the long-run indicate } \\
\text { that, for the case of skilled and unskilled labor productivity, skilled labor productivity } \\
\text { maintained a negative effect on the wage level and the unskilled labor productivity had a } \\
\text { positive effect on the wage level. In addition, the total labor productivity had a positive impact } \\
\text { on the wage level; the results also indicate that the level of education had a positive impact on } \\
\text { the wage level and the impact of government size on the level of wage was negative and } \\
\text { statistically insignificant. }\end{array}$ \\
\hline
\end{tabular}
\end{abstract}

(C) 2017 by the authors; licensee Growing Science, Canada.

\section{Introduction}

Human capital is one of the important factors for the growth and development of each country. Unlike other resources that have an impact on economic growth, labor has a maturity level and is also more effective at using other production factors (Nikulin, 2015). Different countries have been struggling to improve their labor productivity to increase their human capital to achieve their goals and sustainable development (Romer, 1990). Studies also show that some countries that are weaker in terms of natural resources than the rest of the world have, by using their human resources development, to grow more than countries with rich sources of natural resources and poor human capital (Pesaran \& Shin, 1998). The productivity of labor increases with increasing and expanding human resource skills through the use of advanced technology; which yields to increasing the labor productivity and ultimately an increase on the level of wages (McCullough, 2017). Studies show that increasing the skill and productivity of the workforce through education and new technologies will increase wage inequality between skilled and unskilled labor and affect wages (Solow, 1980; Coccia, 2017).

* Corresponding author. Tel.: +98-913-2552500

E-mail address: sb.fazayel@gmail.com (S. B. Fazayel Ardakani) 
Wages and labour productivity are considered as economic indicators and their relationship has been analysed by economists and politicians. Relationship between wages and labour productivity is vital for every region or economic sector. Tamašauskienė and Stankaitytė (2013) studied the relationship between wages and labour productivity in Lithuania by regions and economic sectors and reported that regional dissimilarities of labour productivity were greater than of wages. In fact in their survey, dissimilarities of wages were higher than labour productivity. Solow (1980) explored some reason on why wage stickiness could be important for employer by investigating the relationship between productivity and the wage rate. Nikulin (2015) tried to figure out the extent to which relative labor productivity and relative unemployment rate changes detect the relative wage changes. They applied average annual macro-data for Poland and other 5 new EU members including Estonia, Hungary, Slovak, Czech Republic and Slovenia for the period 2002-2013. They tested the correlation between wage, productivity and unemployment rate changes in these countries using Poland as benchmark, Then, they examined the elasticities of the relative wage changes with regard to relative productivity and unemployment differences using panel data model. They discovered that the trajectory of wage, productivity and unemployment rate development in new EU member countries was well diversified. They also reported a strong relationship between wage and productivity ratio changes in Poland associated with Czech Republic, Estonia and Hungary. Doan and Gente (2014) developed a two-sector specific factor model in which capital was mobile between sectors. They assumed that the traded (nontraded) sector implemented skilled (unskilled) labor for production. The theoretical model also disclosed that the real exchange rate (RER) response to a productivity shock relied on the countries' relative abundance of skilled labor. They also confirmed that the skilled versus unskilled labor ratio could be a significant splitting variable.

Various factors affect the productivity of labor force, one of which is the level of education and training. As a result, one of the ways to increase the labor productivity is to increase the skill through education, and different countries are requested to increase the productivity of their workforces. The growth in labor productivity means that more goods are produced in a business or in one country over a given period. On the other hand, with the expansion of other economic complexities, traditional wage systems do not create a strong incentive to work and produce more in firms; they are not responsive to the economic environment of today's enterprises, and they even have no role to play in increasing labor productivity (Tamašauskienė \& Stankaitytė, 2013). The relationship between wages and labor productivity combined with industrial development and enterprise outbreaks were introduced in new ways in the field of economic activity, and with their growth, a variety of wage regimes coincided with the output and volume of production.

In all wage systems, part of the wage, or all of that, is linked to the productivity of the individuals. In the wake of these developments, today, paying attention to the workforce, based on its results and achievements, is very important. Therefore, it is important to identify a clear relationship between the productivity and the level of wages for skilled and unskilled laborers. In this paper, we study the effect of skilled and unskilled workforce productivity as well as total labor productivity on wages in Iran during the period of 1974-2014 using Autoregressive Distributed Lag Modelling Approach (ARDL) and the effect of each case is compared with the amount of wages.

\section{Literature review}

Economic theories suggest any increase on real wages only depends on labor productivity. Bester and Petrakis (2003) studied the relationship between wages and productivity growth in a competitive industry with free entry and exit. The results of this research indicated that in the long-run, the wages paid by firms determine the productivity. Acevedo (2003) reported that both employers and workers benefit from investment in education, skills and experience, and suggested that education had a significant impact on wages and productivity, and that wages and productivity were affected by education. Klein (2012) examined the relationship between real wages and labor productivity in South Africa and concluded that real wages with labor productivity had a coherent relationship that, by going beyond sustainable balance, the relationship between real wage growth and the growth of labor 
productivity in the short term weakened. Polemis and Stengos (2015) examined the impact of market structures on labor productivity and wages in some US industries over the period from 1958 to 2007. In this research, the SCSM model was used. The results of this study indicated a nonlinear relationship between market concentration and labor productivity and wages.

Afonso (2016) examined the impact of labor market institutions on employment, wages, research intensity, and development and growth in 27 OECD countries over the period 1991-2008. In this paper, the literature on the subject focused on the implications of financial institutions: 1. Unskilled labor employment 2. Inequality of wages in favor of skilled workers $3 . \mathrm{R} \& \mathrm{D}$ intensity and 4 . Economic growth. The results of this survey showed that European countries had the largest share of skilled labor. Eastern European countries had the highest surplus of research and development, with the Nordic countries having the highest rates of research and development. East Asian countries also had the largest share of non-productive labor in production.

As we have seen, studies in Iran and the world have been conducted on the effects of productivity and wages, and in none of them, the effect of labor productivity was determined by the number of skilled and unskilled laborers on the level of wages. In this paper, using the data of the country of Iran during the period of 40 years over the period 1974-2014 we examine the effect of total labor productivity on wages and the effect of the productivity of skilled and unskilled labor on the wage level.

\section{The proposed study}

The proposed study of this paper uses the following model.

$$
\begin{aligned}
& W_{t}=\alpha_{1}+\alpha_{2} \text { Pros }_{t}+\alpha_{3} \text { Prou }_{t}+\alpha_{4} G_{t}+\alpha_{5} E d u_{t}+u_{t}, \\
& W_{t}=\alpha_{1}+\alpha_{2} \text { Pros }_{t}+\alpha_{3} \text { Prou }_{t}+\alpha_{4} G_{t}+\alpha_{5} E d u_{t}+\alpha_{6} \text { Trend }+u_{t}, \\
& W_{t}=\alpha_{1}+\alpha_{2} \text { Prot }_{t}+\alpha_{3} G_{t}+\alpha_{4} E d u_{t}+u_{t}, \\
& W_{t}=\alpha_{1}+\alpha_{2} \text { Prot }_{t}+\alpha_{3} G_{t}+\alpha_{4} E d u_{t}+\alpha_{5} \text { Trend }+u_{t},
\end{aligned}
$$

where $W_{t}$ is the dependent variable and represents the wages, Prot $t_{\text {, Prost }}$ and Prout denote the total productivity, skilled and unskilled productivity, respectively. Moreover, $E d u_{t}, G_{t}$ and Trend represent the educational level, size of the government and time, respectively. Finally, $\alpha_{\mathrm{i}}, i=1, \ldots, 6$ are estimated parameters and $u_{t}$ is the residual. The models will be estimated logarithmically, with coefficients representing elasticities. Here, $W$ is the total wage index and salaries and benefits, which were paid to employees of large industrial Iranian corporations and they were extracted from the official reports from central bank. Productivity is computed from different sectors. Per capita value added is computed by dividing the value added of each industry sector by the number of the employees who worked in that sector. The classification of skilled and unskilled labor force is also determined based on the tradeable and non-tradable sectors. We assume that tradeable industries use skilled workers and nontradable industries use unskilled workers (Doan \& Gente, 2014). Statistics on the productivity of the economic sectors are collected from the National Productivity Organization and the Center for Statistics of Iran. $G$ statistics represents the size of the government (government expenditure divided by GNP) from the central bank. In addition, $E d u$ is the average of years of education that is used as a proxy for the level of literacy and education of employed people, which has been extracted from the organization of management and planning in Iran.

To avoid bad regressions using the Dickey Fuller unit root test, the reliability of the variables used has been verified. The results of the survey indicate that the variables of unskilled and labor productivity were stationary, and the remaining variables were not stationary and end up to become stable after performing the first-order difference and finally the ARDL method could be used to estimate the model. Analysis is executed in two parts. In the first part, the workforce was divided into two parts of the skilled and unskilled labor forces and the effects of each one on the wage were examined, and in the second section, the effects of total labor productivity on wages were examined. In addition, estimates of the model were investigated under two circumstances of with and without time trends; this is performed to examine the relationship between the wage level and the productivity of the following steps. In the first stage, the short-run relationship between labor productivity and the level of wages 
were investigated while in the second stage, the long-run relationship between the variables of the model was tested and, if there were a long-term relationship, this relationship would be estimated and finally, the ECM model was evaluated.

\subsection{Productivity of skilled and unskilled workers}

In this section, the workforce is divided into two skilled and unskilled sectors to examine the effect of each on the wage level. Therefore, in this section, the effect of skilled labor force productivity and unskilled labor productivity on the wage level under two circumstances of with and without time trend according to the Eq. (1) and Eq. (2) were examined.

\subsubsection{Productivity of skilled and unskilled workers in short term}

According to the results of Table 1 and Table 2 in the short run, the wage of the previous period has a positive and significant effect on the current wage, indicating that the wage of the previous period is higher, the wages in the current period are also higher. The productivity of the skilled labor has a negative and significant effect on the current wage level. Skilled labor productivity in previous periods has a negative effect on the wage level of the current period. The rate of unskilled labor productivity has a positive and significant effect on the wage level; the effect of the size of the government on the level of wages is insignificant. The level of education also has a positive and significant effect on the level of wages. The variable trend according to Table 2 has a positive and significant effect on the wage level.

Table 1

The short-run relationship between skilled and unskilled labor productivity and the level of wages without time trend

\begin{tabular}{ccccc}
\hline Variable & Coefficient & Standard error & t-Statistics & Prob \\
\hline LW(-1) & 0.888 & 0.038 & 23.027 & 0.000 \\
LPros & -0.333 & 0.164 & -2.026 & 0.050 \\
LProu & 0.690 & 0.133 & 5.180 & 0.000 \\
LG & -0.133 & 0.085 & -1.559 & 0.120 \\
Ledu & 2.172 & 0.386 & 5.622 & 0.000 \\
C & -10.478 & 1.999 & -5.240 & 0.000 \\
\hline $\mathrm{R}^{2}$ & & 0.997 & & \\
D-W & & 2.149 & & \\
\hline
\end{tabular}

Table 2

The short-run relationship between skilled and unskilled labor productivity and the level of wages with time trend

\begin{tabular}{ccccc}
\hline Variable & Coefficient & Standard error & t-Statistics & .Prob \\
\hline LW(-1) & 0.535 & 0.072 & 7.406 & 0.000 \\
LPros & -0.553 & 0.255 & -2.162 & 0.040 \\
LPros(-1) & -0.405 & 0.305 & -1.328 & 0.190 \\
LPros(-2) & -0.595 & 0.247 & -2.409 & 0.020 \\
LProu & 0.486 & 0.206 & 2.356 & 0.020 \\
LProu(-1) & 0.518 & 0.244 & 2.119 & 0.040 \\
LG & -0.143 & 0.076 & -1.887 & 0.070 \\
LEdu & -0.007 & 0.852 & -0.008 & 0.990 \\
LEdu(-1) & 2.066 & 0.881 & 2.344 & 0.020 \\
C & 6.754 & 2.259 & -2.989 & 0.000 \\
Trend & 0.118 & 0.022 & 5.254 & 0.000 \\
\hline R & & 0.999 & & \\
\hline D-W & & 2.144 & & \\
\hline
\end{tabular}

If the sum of the coefficients of the variables with interruptions associated with the dependent variable is less than one, the short-run pattern tends toward a long-term equilibrium pattern. The t-test quantity for this test is 23.38 for the model without time trend and 7.43 for the model with time trend. Since the critical value provided by Benjering-Dawlado is $90 \%$ and less than $\beta$ in the confidence level, the $\mathrm{H}_{0}$ 
hypothesis is rejected and this indicates the existence of an equilibrium relationship in long-term relationships 1 and 2 .

\subsubsection{Productivity of skilled and unskilled workers in long term}

According to Table 4, the trend variable has a positive and significant effect, but to ensure the model is considered for both cases of with and without trends. According to Table 3 and Table 4, in the long run, skilled labor productivity has a negative effect on the wage level, which in the model without the trend is insignificant and in the model with the trend, this effect is significant. However, the effect of labor productivity on unskilled workers and the level of education in the long run is statistically significant and positive. In addition, the effect of the government size on the level of wages is negative, but statistically insignificant.

\section{Table 3}

Investigating the long-run relationship between the productivity of skilled and unskilled workers and the level of wages without trends

\begin{tabular}{ccccc}
\hline Variable & Coefficient & Standard error & t-Statistics &. Prob \\
\hline LPros & -3.0000 & 2.283 & -1.313 & 0.19 \\
LProu & 6.206 & 2.034 & 3.051 & 0.00 \\
LEdu & 19.526 & 5.059 & 3.859 & 0.00 \\
LG & -1.196 & 0.949 & -1.260 & 0.21 \\
C & -94.170 & 21.707 & -4.338 & 0.00 \\
\hline
\end{tabular}

\section{Table 4}

Investigating the long-run relationship between the productivity of skilled and unskilled workers and the level of wages with trends

\begin{tabular}{|c|c|c|c|c|}
\hline Variable & Coefficient & Standard error & t-Statistics & .Prob \\
\hline LPros & -3.348 & 0.561 & -5.957 & 0.00 \\
\hline LProu & 2.165 & 0.299 & 7.233 & 0.00 \\
\hline LEdu & 4.437 & 0.938 & 4.727 & 0.00 \\
\hline $\mathrm{LG}$ & -0.309 & 0.173 & -1.789 & 0.08 \\
\hline $\mathrm{C}$ & -14.554 & 5.281 & -2.755 & 0.01 \\
\hline Trend & 0.255 & 0.026 & 9.688 & 0.00 \\
\hline
\end{tabular}

\subsubsection{Error Correction Mechanism}

Table 5 and Table 6 show the error correction mechanism for the corresponding ARDL. The coefficient of correction with no time trend is ECM $(-1)=-0.111$ and in the pattern with a time trend is ECM $(-1)$ $=-0.464$, which indicates the relative velocity of the modulation period.

\section{Table 5}

The Error Correction Mechanism without time trend

\begin{tabular}{ccccc}
\hline Variable & Coefficient & Standard error & t-Statistics & .Prob \\
\hline dLPros & -0.333 & 0.164 & -2.026 & 0.05 \\
dLProu & 0.690 & 0.133 & 5.180 & 0.00 \\
dLEdu & -10.478 & 1.999 & -5.240 & 0.00 \\
dLG & -0.133 & 0.085 & -1.559 & 0.12 \\
dC & -10.478 & 1.999 & -5.240 & 0.00 \\
ecm $(-1)$ & -0.111 & 0.038 & -2.883 & 0.00 \\
\hline $\mathrm{R}^{2}$ & & 0.516 & & \\
D-W & & 2.149 & & \\
\hline
\end{tabular}


Table 6

The Error Correction Mechanism with time trend

\begin{tabular}{ccccc}
\hline Variable & Coefficient & Standard error & t-Statistics & Prob \\
\hline dLPros & -0.553 & 0.255 & -2.162 & 0.03 \\
DLPros 1 & 0.595 & 0.247 & 2.409 & 0.02 \\
dLProu & 0.486 & 0.206 & 2.356 & 0.02 \\
dLEdu & -0.007 & 0.852 & -0.008 & 0.99 \\
dLG & -0.143 & 0.076 & -1.887 & 0.06 \\
dC & -6.754 & 2.259 & -2.989 & 0.00 \\
dTrend & 0.118 & 0.022 & 5.254 & 0.00 \\
ecm(-1) & -0.464 & -0.072 & -6.414 & 0.00 \\
\hline $\mathrm{R}^{2}$ & & 0.768 & & \\
D-W & & 2.144 & & \\
\hline
\end{tabular}

\subsection{Total productivity}

In this section, the effect of total workforce productivity on the wage level is investigated according to Eq. (3) and Eq. (4) under two circumstances of with and without time trends.

\subsubsection{The effect of total productivity in short term}

According to the results obtained in Table 7 and Table 8, there is a significant and positive effect on the wages of the previous period and the wages of the two previous periods have a negative and significant effect on the current wage level. Total workforce productivity has a positive and significant effect on the wage level. The level of education also has a positive effect on the wage level. This effect is statistically significant in the model without time trend and is statistically insignificant in the model with the time trend. The effect of government size on wage levels is also insignificant. The effect of the trend on the wage level is unreasonable.

Table 7

Investigating the short-run relationship between total productivity and wages without time trend

\begin{tabular}{ccccc}
\hline Variable & Coefficient & Standard error & t-Statistics & .Prob \\
\hline LW(-1) & 1.396 & 0.143 & 9.756 & 0.00 \\
LW(-2) & -0.504 & 0.134 & -3.750 & 0.00 \\
LProt & 0.330 & 0.110 & 2.986 & 0.00 \\
LG & -0.015 & 0.080 & -0.195 & 0.84 \\
LEdu & 0.704 & 0.295 & 2.384 & 0.02 \\
C & -2.068 & 0.673 & -3.069 & 0.00 \\
\hline $\mathrm{R}^{2}$ & & 0.999 & & \\
D-W & & 1.997 & &
\end{tabular}

\section{Table 8}

Investigating the short-run relationship between total productivity and wages with time trend

\begin{tabular}{ccccc}
\hline Variable & Coefficient & Standard error & t-Statistics & .Prob \\
\hline LW(-1) & 1.386 & 0.151 & 9.168 & 0.00 \\
LW(-2) & -0.510 & 0.139 & -3.663 & 0.00 \\
LProt & 0.300 & 0.172 & 1.748 & 0.09 \\
LG & 0.976 & 0.109 & 0.008 & 0.99 \\
LEdu & 0.630 & 0.441 & 1.425 & 0.16 \\
C & -1.805 & 1.338 & -1.348 & 0.18 \\
Trend & 0.005 & 0.025 & 0.228 & 0.82 \\
\hline $\mathrm{R}^{2}$ & & 0.999 & & \\
D-W & & 2.004 & & \\
\hline
\end{tabular}

\subsubsection{Estimating long term relationship}

Table 9 and Table 10 show the long-term relationship between wages and explanatory variables. The results indicate that the effect of the time trend variable in the long run is statistically insignificant, but to ensure both models with and without time trends have been examined. Total labor productivity in the long run has a positive impact on the wage level, which is statistically significant. The impact of 
government size in both models is statistically insignificant. In addition, the level of education has a positive impact on the wage level, which is statistically significant in the absence of trend.

Table 9

Investigating the long-run relationship between the total productivity on wages without time trend

\begin{tabular}{ccccc}
\hline Variable & Coefficient & Standard error & t-Statistics &. Prob \\
\hline LProt & 3.057 & 0.980 & 3.119 & 0.00 \\
LG & -0.144 & 0.764 & -0.189 & 0.85 \\
LEdu & 6.514 & 0.636 & 10.226 & 0.00 \\
C & -19.131 & 4.497 & -4.254 & 0.00 \\
\hline
\end{tabular}

Table 10

Investigating the long-run relationship between the total productivity on wages with time trend

\begin{tabular}{ccccc}
\hline Variable & Coefficient & Standard error & t-Statistics & .Prob \\
\hline LProt & 2.420 & 2.542 & 0.951 & 0.34 \\
LG & 0.007 & 0.874 & 0.008 & 0.99 \\
LEdu & 5.070 & 5.558 & 0.912 & 0.36 \\
C & -14.529 & 17.847 & -0.814 & 0.42 \\
Trend & 0.046 & 0.177 & 0.261 & 0.79 \\
\hline
\end{tabular}

\subsubsection{Error Correction Mechanism}

Table 11 and Table 12 show the error correction mechanism for the corresponding ARDL. The coefficient of correction with no time trend is ECM $(-1)=-0.108$ and in the pattern with a time trend is ECM $(-1)=-0.124$, which indicates the relative velocity of the modulation period.

\section{Table 11}

The Error Correction Mechanism without time trend

\begin{tabular}{ccccc}
\hline Variable & Coefficient & Standard error & t-Statistics &. Prob \\
\hline DWl & 0.504 & 0.134 & 3.750 & 0.00 \\
dLProt & 0.330 & 0.110 & 2.986 & 0.00 \\
dLG & -0.015 & 0.080 & -0.195 & 0.84 \\
dLEdu & 0.704 & 0.295 & 2.384 & 0.02 \\
Dc & -2.068 & 0.673 & -3.069 & 0.00 \\
ecm(-1) & -0.108 & 0.040 & -2.666 & 0.01 \\
\hline $\mathrm{R}^{2}$ & & 0.446 & & \\
D-W & & 1.997 & & \\
\hline
\end{tabular}

Table 12

The Error Correction Mechanism with time trend

\begin{tabular}{ccccc}
\hline Variable & Coefficient & Standard error & t-Statistics &. Prob \\
\hline dLW1 & 0.510 & 0.139 & 3.663 & 0.00 \\
dLProt & 0.300 & 0.172 & 1.748 & 0.09 \\
dLG & 0.976 & 0.109 & 0.008 & 0.99 \\
dLEdu & 0.630 & 0.441 & 1.425 & 0.16 \\
dC & -1.805 & 1.338 & -1.348 & 0.18 \\
dTrend & 0.005 & 0.025 & 0.228 & 0.82 \\
ecm(-1) & -0.124 & 0.081 & -1.521 & 0.13 \\
\hline $\mathrm{R}^{2}$ & & 0.447 & & \\
D-W & & 2.004 & & \\
\hline
\end{tabular}

\section{Conclusion}

This research has investigated the effect of labor productivity on the wage level, which has been investigated in several ways. In the first case, the workforce was divided into two parts: skilled and unskilled, and their effects on the wage level was investigated. The results show that in the long run, skilled labor productivity has a negative effect on the wage level; this can be attributed to the fact that leisure for skilled labor is a Giffen good, and the supply function for these people has a negative slope. 
In addition, unskilled labor productivity has maintained a positive effect on the wage level, since leisure for unskilled labor is a luxury good and the supply function for these people has had a positive slope. Education has also had a positive impact on the wage level. It can be argued that education is one of the most important factors in the transformation of labor into human capital, that is, an educated workforce leads to technological innovation and progress, which results in the ultimate production of workers. The effect of government size on the level of wages is negative and statistically insignificant. Although this coefficient is statistically insignificant, it can be said that increasing the size of the government means reducing the size of the private sector, and reducing the size of the private sector will reduce the growth of production and productivity. For the latter case, the effect of total labor productivity on the wage level was examined. The results show that the effect of total labor productivity and education level on the level of wage was positive and significant, but the impact of government size on the level of wages was not significant.

\section{Acknowledgement}

The authors would like to thank the anonymous referees for constructive comments on earlier version of this paper.

\section{References}

Acevedo, G. L. (2003). Wages and productivity in Mexican manufacturing (Vol. 2964). World Bank Publications.

Afonso, Ó. (2016). Effects of labour-market institutions on employment, wages, R\&D intensity and growth in 27 OECD countries: From theory to practice. Economic Modelling, 53, 48-62.

Bester, H., \& Petrakis, E. (2003). Wages and productivity growth in a competitive industry. Journal of Economic Theory, 109(1), 52-69.

Coccia, M. (2017). Optimization in R\&D intensity and tax on corporate profits for supporting labor productivity of nations. The Journal of Technology Transfer, 1-23.

Doan, T. H. T., \& Gente, K. (2014). Real exchange rate and productivity in a specific-factor model with skilled and unskilled labour. Journal of Macroeconomics, 40, 1-15.

Klein, N. (2012). Real wage, labor productivity, and employment trends in South Africa: A closer look (No. 12-92). International Monetary Fund.

McCullough, E. B. (2017). Labor productivity and employment gaps in Sub-Saharan Africa. Food Policy, 67, 133-152.

Nikulin, D. (2015). Relationship between wages, labour productivity and unemployment rate in new EU member countries.

Pesaran, M. H., \& Shin, Y. (1998). An autoregressive distributed-lag modelling approach to cointegration analysis. Econometric Society Monographs, 31, 371-413.

Polemis, M. L., \& Stengos, T. (2015). Does market structure affect labour productivity and wages? Evidence from a smooth coefficient semiparametric panel model. Economics Letters, 137, 182-186.

Romer, P. M. (1990). Capital, labor, and productivity. Brookings papers on economic activity. Microeconomics, 1990, 337-367.

Solow, R. M. (1980). Another possible source of wage stickiness. Journal of macroeconomics, 1(1), $79-82$.

Tamašauskienè, Z., \& Stankaitytè, A. (2013). Evaluating of the Relationship between Wages and Labour Productivity in Lithuania: Territorial and Sectoral Approaches. Socialiniai tyrimai, (1), 2435.

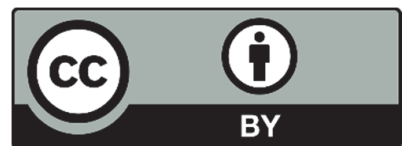

(C) 2018 by the authors; licensee Growing Science, Canada. This is an open access article distributed under the terms and conditions of the Creative Commons Attribution (CC-BY) license (http://creativecommons.org/licenses/by/4.0/). 